\title{
Salmonella enterica subsp houtenae SEROGROUP 0:16 IN A HIV POSITIVE PATIENT: CASE REPORT
}

Maria Cristina S. LOURENÇO(2), Eliane Falavina M. dos REIS(1), Rogério VALLS(2), Marise Dutra ASENSI(1) \& Ernesto HOFER(1)

\section{SUMMARY}

We described a case of salmonellosis in a 33-year old HIV-infected patient. The patient presented oral and esophageal candidiasis, intense epigastric and retrosternal pain. During the physical examination he was hypochloraemic, acyanotic, hypohydrated, anicteric and afebrile. Admittance laboratorial tests indicated: red cells 3.6 millions $/ \mathrm{mm}^{3}$; hemoglobin, $10.1 \mathrm{~g} / \mathrm{dL}$; leukocyte count, 3,000/mm $\mathrm{m}^{3}$, with $1 \%$ of eosinophils, $14 \%$ of non-segmented and $53 \%$ of segmented neutrophils and $31 \%$ of lymphocytes. The blood culture was positive for Salmonella enterica subsp houtenae serogroup O:16. This is probably the first human report of bacteremia due to Salmonella enterica subsp houtenae in Brazil associated to HIV-infected patient.

KEYWORDS: Salmonellosis; S. houtenae; HIV patient; Blood culture.

\section{INTRODUCTION}

Salmonellosis is an important zoonosis in devoloping countries. It is widely disseminated within animals, affecting homeothermic and poikilothermic species, which is an infection source. Main dissemination routes are represented by contaminated food and water.

Salmonella genus presents two species: S. bongori and S. enterica and six subspecies (I a VI), called enterica, salamae, arizonae, diarizonae, houtenae and indica. Salmonella enterica subsp enterica presents the greatest number of serovars (2480) and it is often related to human and animal pathological processes, mostly Enteritidis, Agona, Infantis, Typhimurium, Heidelberg and Dublin serovars.

Although Salmonella enterica subsp houtenae currently comprises 71 distinct serovars (POPOFF \& LE MINOR, 2001) human infections due to this microorganism are rarely documented, with less than $1 \%$ of isolations (TAUNAY et al., 1996; TAVECHIO et al., 2002). We report the isolation of this species of Salmonella from blood culture of a HIVinfected patient in Rio de Janeiro, Brazil.

\section{CASE REPORT}

A 33-year-old man, white, single, was attended at Instituto de Pesquisa Evandro Chagas (IPEC)/Fundação Oswaldo Cruz/FIOCRUZ, an infectious and parasitical diseases hospital unity, on August $10^{\text {th }}, 2002$, complaining of intense epigastric pain and retrosternal pain.

The patient has had an irregular follow up in IPEC since 1996, when he sought medical assistance due to an AIDS related disease, the criptococcal meningitis. At that moment his blood test for HIV infection was positive and confirmed the sign and symptoms. He reported drug addiction and had low adherence to the antiretroviral drugs and prophylaxis prescribed. The last CD4+ T-cell count (September 2000) was 60 (Facs Count - Becton \& Dickson) and viral load was 330000
(5,52 log) (NASBA test - Organon). He lived in a brick house in Rio de Janeiro periphery with piped water and cohabited with dogs and birds. On the physical examination he was pale, hypochloraemic, acyanotic, anicteric, hypohydrated with massive oral and esophageal candidiasis. Blood pressure and axilar temperature were normal.

At patient's admittance, CBC analysis indicated: red cells 3.6 millions $/ \mathrm{mm}^{3}$; hemoglobin, $10.1 \mathrm{~g} / \mathrm{dL}$; leukocyte counting, $3,000 / \mathrm{mm}^{3}$, with $1 \%$ of eosinophils, $14 \%$ of bands; $53 \%$ of polymorphs/neutrophils and $31 \%$ of lymphocytes. Dosages of bilirubin, ALT, AST, glucose, urea, creatinine, chlorine, sodium, potassium and albumin were at normal levels. Gamma glutamyl transferase dosage was $210 \mathrm{~g} / \mathrm{dL}$. Abdominal ultrasound revealed homogenous splenomegaly, with no further alterations. Three blood cultures were collected and referred to Bacteriology Laboratory in IPEC.

The patient remained afebrile and without diarrhea until the third day in the hospital when fever of $38.5^{\circ} \mathrm{C}$ was detected. On the same day, was given ciprofloxacin (500 mg, 12/12h) and the Bacteriology Laboratory informed that two of three blood samples showed bacterial growth. After the third day of treatment, fever and epigastric pain yielded and, on August 20, 2002 he was dismissed.

Blood cultures were done through BACTEC 9050 system (BioMérieux) and, at the first sign of bacterial growth, it was subcultivated on Agar Blood plates (Columbia Agar Base -MERCK with 5\% of defibrinated sheep blood - produced by FIOCRUZ), incubated at $37{ }^{\circ} \mathrm{C}$ in aerobic conditions. After $24 \mathrm{~h}$-incubation period, isolated colonies were identified through API 20E system (BioMérieux), as Salmonella and serotyped according to POPOFF \& LE MINOR (2001).

According to the results of the phenotypical characteristics used to differentiate Salmonella species and subspecies (POPOFF \& LE MINOR 2001), the strain was identified as S. enterica subsp houtenae based on the following biochemical tests: production of acids from: lactose

(1) Laboratório de Enterobactérias do Instituto Oswaldo Cruz- IOC/FIOCRUZ, Rio de Janeiro, RJ, Brazil

(2) Instituto de Pesquisa Clínica Evandro Chagas-IPEC/FIOCRUZ, Rio de Janeiro, RJ, Brazil

Correspondence to: Dr. Ernesto Hofer, Laboratório de Enterobactérias do Instituto Oswaldo Cruz, IOC/FIOCRUZ, Av. Brasil 4365, 21045-900 Rio de Janeiro, RJ, Brazil 
(negative), dulcitol (negative), salicine (positive), sorbitol (positive); decarboxylation of lysine (positive) and ornithine (positive) and ability to utilize malonate as a single source of carbon (negative).

Antigenic characterization was carried out by slide agglutination test according to POPOFF \& Le MINOR (2001), using somatic and flagellar antisera, including those for $\mathrm{R}$ phases of $\mathrm{H}$ antigens. All antisera were either commercially available (Sanofi/Pasteur Institute, France) or prepared at Laboratório de Enterobactérias/ Departamento de Bacteriologia/ Instituto Oswaldo Cruz. According to the biochemical and serological profiles the strain was characterized as Salmonella enterica subsp houtenae O16:HNT (non-typable H-antigen). This procedure characterized the microorganism as Salmonella enterica subsp houtenae serogroup $\mathrm{O} 16$.

The disk diffusion method of susceptibility testing performed according to NCCLS (2001) allowed us to classify the strain as susceptible to the following antimicrobials (OXOID): ampicillin, cephalothin, cefoxitin, ceftriaxone, gentamicin, amikacin, ciprofloxacin, sulfamethoxazole-trimethoprim, chloramphenicol and tetracycline.

\section{DISCUSSION}

Human infections associated with Salmonella enterica subsp houtenae are rarely reported. In Brazil, TAUNAY at al. (1966) showed among 31,517 Salmonella strains from human sources and 14,345 strains from non-human origins, isolated between 1950 and 1990, only $0.060 \%$ and $0.22 \%$, respectively corresponded to this subspecies.

More recently, TAVECHIO et al. (2002), also in Brazil, reported that less than $1 \%$ of 4,581 Salmonella strains isolated from non-human sources between 1966 and 2000 belonged to S. enterica subsp houtenae.

On the other hand, RUNKEL et al., 1991, in Texas, USA, showed that $69 \%$ of opossums (Didelphis virginiana) from Florida harbored $S$. enterica subsp houtenae in several anatomical sites. They described the invasiveness of this organisms showing the occurrence of high frequency of focal disease in the biliary tract, translocation into regional lymph nodes, and hematogenous spread to the reticuloendothelial system in these animals. Despite the systemic spread of this organism, the great majority of opossums showed no signs of acute illness.

We did not find, in medical literature, any report about human cases which registered the presence of $S$. enterica subsp houtenae associated to HIV-infected patient.

Two aspects should be considered in this report: the first is due to the fact that the patient was HIV positive for six years leading to a long history of immunosuppression, and the second is related to the low adhesion for antiretroviral treatment. These conditions favoured the illness and may have accounted for increasing the possibility of acquiring an infection with an organism rarely found in human infections and extremely susceptible to antimicrobials. In this way, SOLA et al. (1998) related that in immunocompetent adults the non-typhi Salmonella infection is limited to gastroenteritis disease. Nevertheless in HIV patient the non-typhi Salmonella infection is 20-100 times more frequent than the population and the bloodstream invasion is 100 times more prevalent than immunocompetent subjects (FERNANDEZ GUERRERO et al., 1997). The most frequent serovar in HIV infection is $S$. Enteritidis. Recently, GORDON et al. (2002) has shown high mortality (47\%) and frequent recrudescence (43\%) with non-typhi Salmonella bacteraemia among HIV-infected Malawian adults.
It is important to consider the fact that the patient cohabited with birds and dog, which might have served as Salmonella reservoirs, as well as the possibility of contamination through ingested food, although there was no intestinal repercussion (diarrhea).

This report may serve as an alert in the search for bacteriological diagnosis in clinical cases of HIV positive patients with or without fever and splenomegaly, as well as to emphasize clinical signs that do not occur as in classical salmonellosis cases. Early diagnosis and treatment could provide advantages for life quality and management of these patients.

\section{RESUMO}

\section{Salmonella enterica subsp houtenae sorogrupo 0:16 em um paciente HIV positivo: relato de caso}

Descreve-se um caso clínico de salmonelose ocorrido em paciente HIV positivo de 33 anos, portador de candidíase oral e esofágica, com intensa dor abdominal superior e dor retro-esternal. Ao exame clínico apresentou-se hipocorado, acianótico, hipohidratado, anictérico e afebril. A investigação laboratorial na admissão apresentou: hemácias, 3,6 milhões/ $\mathrm{mm}^{3}$; hemoglobina, $10,1 \mathrm{~g} / \mathrm{dL}$; contagem de leucócitos, $3.000 / \mathrm{mm}^{3}$, com $1 \%$ de eosinófilos, $14 \%$ de bastões; $53 \%$ de neutrófilos segmentados e $31 \%$ de linfócitos. A hemocultura foi positiva para Salmonella enterica subsp houtenae sorogrupo O:16. Provavelmente, este é o primeiro relato de caso clínico humano com bacteremia causado por Salmonella enterica subsp houtenae no Brasil associado a paciente HIV-infectado.

\section{ACKNOWLEDGMENT}

To Dr. Dália dos Prazeres Rodrigues, chief of Laboratório de Enterobacterias/IOC/FIOCRUZ, for technical support.

\section{REFERENCES}

1. FERNANDEZ GUERRERO, M.L.; RAMOS, J.M.; NUNEZ, A.; NUNEZ, A. \& DE GORGOLAS, M. - Focal infection due to non-typhi Salmonella in patients with AIDS: report of 10 cases and review. Clin. infect. Dis., 25: 690-697, 1997.

2. GORDON, M.A.; BANDA H.T.; GONDWE M. et al. - Non-typhoidal Salmonella bacteraemia among HIV-infected Malawian adults. AIDS, 16: 1633-1641, 2002.

3. NATIONAL COMMITTEE FOR CLINICAL LABORATORY STANDARDS Performance Standards for Antimicrobial Susceptibility Testing. NCCLS Publication M 100-S 11, 2001.

4. POPOFF, M.Y. \& LE MINOR, L. - Antigenic formulas of the Salmonella serovars. $8^{\text {th }}$ revision. WHO Collaborative Centre for Reference and Research on Salmonella. Paris, Institut Pasteur, 2001.

5. RUNKEL, N.S.; RODRIGUEZ, L.F.; MOODY, F.G., LaROCCO, M.T. \& BLASDEL, T - Salmonella infection of the biliary and intestinal tract of wild opossums. Lab. anim. Sci., 41: 54-56, 1991.

6. SOLA, J.; CASTIELLO, U.J.; REPÁRAZ, J. \& SOLA, O. - Infecciones bacterianas en pacientes infectados por el VIH. An. Sist. Sanit. Navar., 21: 319-329, 1998.

7. TAUNAY, A.E.; FERNANDES, S.A.; TAVECHIO, A.T. et al. - The role of public health laboratory in the problem of salmonellosis in São Paulo, Brazil. Rev. Inst. Med. trop. S. Paulo, 38: 119-127, 1996.

8. TAVECHIO, A.T.; GHILARDI, A.C.R.; PERESI, J.T.M. et al. - Salmonella serotypes isolated from nonhuman sources in São Paulo, Brazil, from 1996 through 2000. J. Food protect., 65: 1041-1044, 2002.

Received: 6 October 2003

Accepted: 15 April 2004 